\title{
A Comparative Analysis of the Socio-economic Potential of Polish Regions ${ }^{1}$
}

\begin{abstract}
Socio-economic potential is one of the key determinants of regional development. The aim of the paper was to analyse the socio-economic development of 16 NUTS-2 regions in Poland in three selected years: 2005, 2009 and 2013. To identify the positions of individual regions in the rankings, for comparison purposes, selected methods of multidimensional comparative analysis have been implemented: the method of pattern of development proposed by Hellwig, the method of standardised values and the method of ranks. The variables used in the analysis describe demographic potential, labour market, economic situation of inhabitants and level of economic activity, activity and financial stability of local government and socio-technical potential. The results show high diversity of socio-economic potential among Polish NUTS-2 regions, however the level of social potential does not always correspond to the level of economic development. This is particularly the case of Silesian and the poorest Eastern Poland regions. Positions in rankings of analysed regions showed growing diversity in subsequent years. The only region that in all the analysed years maintained its position was the capital region. The results confirmed significant compatibility of the results obtained using different methods which means that in the analysis of socio-economic potential of Polish regions one of them could be used.
\end{abstract}

Keywords: multidimensional comparative analysis; socio-economic potential; Poland; regional analysis

Received: 7 January 2016

Accepted: 26 June 2016

\section{Suggested citation:}

Golejewska, A. (2016). A Comparative Analysis of the Socio-economic Potential of Polish Regions. Prace Komisji Geografii Przemystu Polskiego Towarzystwa Geograficznego [Studies of the Industrial Geography Commission of the Polish Geographical Society], 30(2), 7-22.

\section{INTRODUCTION}

Regional development disparities in Poland, extensively described in the literature, are the result of various factors stemming inter alia from location attractiveness, available natural resources, human capital, access to transport and telecommunication infrastructure and public services. A particular aspect of the research is the issue of socio-economic potential, treated as one of the key determinants of regional development. Despite different forms of regional policy in Poland, there are still great regional disparities that divide the country into two parts: well developed western part and less developed eastern part of the country.

${ }^{1}$ Paper presented at the Regional Studies Association Winter Conference "Great Transformation: Recasting Regional Policy", London, 19-20 November 2015 
The aim of the paper was to analyse the socio-economic development of 16 NUTS2 regions in Poland in three selected years: 2005 - one year after the accession of Poland to the European Union, 2009 - the period of economic downturn resulting from the global economic crisis and 2013 - recent year for which all the data used in the empirical analysis were available. The positions of individual regions in the rankings have been identified using selected methods of multidimensional comparative analysis. The research is based on the Local Data Bank maintained by the National Statistical Office (NSO), data published by the NSO in regional statistical yearbooks, data provided by the Polish Ministry of Finance and Eurostat Regional Statistics.

In the first phase of the study the variables have been selected. The choice was based on current research literature, as well as timeliness, accessibility and comparability of the data. The next step was to reduce potential set of variables taking account of the statistical criteria. After elimination of variables which were highly correlated and were not diversified enough, 15 variables were left to conduct the analysis. Given the natural differences resulting from size and number of inhabitants in the enquiry unit, it must be concluded that each characteristic is relative. Finally, the rankings and clustering of the analysed regions have been provided.

\section{THEORETICAL FRAMEWORK}

Broadly understood development is a fundamental economic concept. A high level of economic development usually creates conditions to ensure a high standard of living to the inhabitants which guarantees adequate access not only to material goods but also to cultural, health and educational services. However, economic development may be accompanied by a range of negative effects, such as environmental degradation, congestion or a rise in house prices.

There is a considerable disagreement over the meaning and measurement of socio-economic development. Economists tend to view development in terms of economic growth, sociologists emphasize importance of the process of social change (Jaffee, 1998; Szirmai, 2015). A concept of socio-economic development covers a general development tendency of a country, region or territorial unit. In fact, it includes the concepts of economic growth, economic development and social development. Socio-economic development embraces changes taking place in the social sphere, mostly of an economic nature. Defining socio-economic development as a series of changes, one shall investigate what characterises those changes and what determines them (Chojnicki, 2010: 8). According to Marciniak, economic development covers production and distribution of goods and services, and social development means changes in social relations, structure of the society, its preferences, social criteria, models of behaviour and attitudes, improving cooperation between people and their participation in results of economic development (Marciniak, 2005). Economic growth, regarded as achievement of economic values, does not necessarily mean an increase in wealth, full satisfaction of needs, and a better distribution of goods (Chojnicki, 2010:15).Socio-economic development restricted to issues of economic growth and modernisation activity cannot be treated as comprehensive approach (Domański, 2004). Therefore, increasingly more 
attention is paid to the role of ecological and civilizational aspects, including environmental protection, and the exploitation of natural resources ${ }^{2}$.

Socio-economic development shall be considered in many mutually penetrating aspects: social, economic, technological, spatial, natural, aesthetic and in timescale. These aspects should be taken into consideration in the socio-economic policy (Bobrowska, Piasecka, 2005: 145). Potential, as defined by Cheymetova et al., means "a source of opportunities, resources and stock, which can be activated and used to solve a problem or achieve a certain goal; capabilities of the individual, society and state in a particular field" (Cheymetova, Nazmutdinova, 2015:79). The socio-economic potential of the area can be defined as "the capacity of the region at the use of the whole complex of its resources, using the characteristics of the existing and future structure of the economy and geographical location in order to improve the quality of life of the population" (Cheymetova, Nazmutdinova, 2015: 75). An important aspect of evaluation of territorial socio-economic potential is to determine its rational structure with an appropriate set of indicators which can be of quantitative, qualitative and structural character. The problem of determining internal reserves of socio-economic development of the region becomes very important. Its solution requires the development of new approaches to the definition of the essence, structure, and methods for assessing the socio-economic potential.

The aim of social and economic activities at the regional level should be in particular welfare gains and improvement of the standard and quality of life of the inhabitants through the development of residential construction, taking care of natural values, improvement of technical and social infrastructure, attracting new investments and activation of local societies. If the tasks are correctly and consistently performed, their effect is likely to be economic advancement of the territorial unit (Bański, Czapiewski, 2008).

Socio-economic development is a complex phenomenon and must be described with more than one variable. These include the following: the number of people below poverty thresholds, data on malnutrition, employment figures, life expectancy at birth, infant mortality, the number of doctors, nurses and hospital beds for every thousand inhabitants, energy consumption, the degree of illiteracy, years of education, data on income distribution, miles of roads and railways, access to clean water, equal opportunities for both men and women, human rights and so forth (Szirmai, 2005: 15). However, in case of regional analysis the data availability is crucial (Stec, 2013; Ziemiańczyk, 2010; Męczyński, Konecka-Szydłowska, Gadziński, 2010; Kopyściański, Rólczyński, 2013).

The present analysis uses the approach applied by Męczyński, Konecka-Szydłowska, Gadziński (Męczyński, Konecka-Szydłowska, Gadziński, 2010) which divided socio-economic variables into five groups: population, economy, social infrastructure, technical infrastructure and housing, and human and social capital. Competitiveness of a region and its future directions of socio-economic development are determined not only by economy but to a large extent by population potential. In turn, the smooth functioning of the economy is not possible without modern technical infrastructure and availability of dwellings. Quality and availability of dwellings significantly affects the

${ }^{2}$ The United Nations Statistics Division developed a list of environmental and related socio-economic indicators. For more, see http://unstats.un.org/unsd/environment/indicators.htm. 
influx of people. In recent years even more important than scale of migration is its quality. In this context the inflow of people with high qualifications and creativity is crucial. Finally, the pace of socio-economic development depends on inhabitants, their social and political activity and public participation.

A convenient way to combine numerous variables into readable results are composite indices, which can aggregate all of the above-mentioned aspects. One of them is the pattern of development suggested by Hellwig, used in the present analysis (Hellwig, 1968: 323-326).

\section{DAtA AND Methodology}

The first applied method was the method of pattern of development proposed by Hellwig (Hellwig, 1968: 323-326). Applying this method allows for carrying out ranking of regions and then their division into classes. This conception was applied and developed in many scientific papers (Hellwig et al., 1994; Zeliaś, 2000; Malina, 2004; Strahl, 2006, Łuczak, Wysocki,2013). The process of construction of the pattern of development starts from identification of elements of observation matrix(characteristic values of selected objects) and then their standardisation.

$X_{j}(j=1,2, \ldots, m)$ denotes characteristic values of selected objects,

$O_{i}(i=1,2, \ldots, n)$ denotes selected objects

$$
z_{i j}=\frac{x_{i j}-\bar{x}_{j}}{s_{j}}
$$

where $\bar{x}_{j}$ denotes arithmetical mean of a characteristic, $S_{j}$ denotes standard deviation of a characteristic.

The next step is the determination of the pattern of development $P_{0}$ with coordinates $\left(z_{01}, z_{02}, \ldots, z_{0 m}\right)$ which is the maximum value for stimulant and the minimum value for de-stimulant.

$$
\begin{aligned}
& z_{O j}=\max _{i} z_{i j} \text {, where } X_{j} \text { denotes stimulant, } \\
& z_{O j}=\min _{i} z_{i j} \text {, where } X j \text { denotes de-stimulant, } j=(1,2, \ldots, m)
\end{aligned}
$$

Then the Euclidean distances between selected objects and established pattern are calculated. Finally, the measure of development for each object is determined (Stec, 2008).

$$
\begin{gathered}
D_{i o=} \sqrt{\sum_{j=1}^{m}\left(z_{i j}-z_{o j}\right)^{2}} \\
i=1, \ldots, n \\
\bar{D}_{o=} n^{-1} \sum_{i=1}^{n} D_{i o}
\end{gathered}
$$




$$
\begin{gathered}
S_{o}=\sqrt{n^{-1} \sum_{i=1}^{n}\left(D_{i o}-D_{o}\right)^{2}} \\
D_{o}=\bar{D}_{o}+2 S_{o}(6) \\
d_{i}=1-\frac{D_{i o}}{D_{o}}, i=1, \ldots, n
\end{gathered}
$$

The closer to one is the measure, the more developed is the object. In this approach, in research concerning more intervals, the model object calculated in the base interval cannot be used directly for subsequent periods of time because when the value of the composite index for the real object is higher than this value for the model object in the base interval, the real object will be considered to be worse than the "ideal" and in fact, it is better. A solution for this problem would be to calculate a new model object for each year, but in this case it would be impossible to compare the results from different intervals. Another solution could be to create one model object for the entire period with the use of all collected data from all previous intervals. However, by doing so one should take into account that the ranking development is calculated (Łatuszyńska, 2012: 71). As the aim of the research was to identify the positions of individual regions in the rankings, a new model object for each year has been calculated.

The next implemented method was the method of standardised values (standardised sum) which is based on the determination of the arithmetical mean of standardised characteristic values of particular objects. In this case, de-stimulants are transformed into stimulants by multiplying their standardised values by -1 . The higher the value of the measure, the more developed is the object.

Finally, the last implemented method was the method of ranks in which, in order to ensure comparability and additivity, ranking of each variable is applied (from 1 to $n$ for stimulants and in reverse order for de-stimulants). The next step is the calculation of the arithmetical mean of the assigned ranks. The lower the value of the measure, the more developed the object.

In the analysis, for comparison purposes, all three methods of multidimensional comparative analysis have been implemented. The synthetic measure assessing the compatibility of rankings obtained using different methods was the Spearman's rank correlation coefficient. Its values range from - 1 for different scores to 1 for compatible scores. The compatibility of rankings is the bigger the closer to 1 is the value of the coefficient.

$$
r_{s}=1-\frac{6 \sum_{i=1}^{n} d_{i}^{2}}{n\left(n^{2}-1\right)}
$$

where $d_{i}$ denotes differences between synthetic ranks, $n$ denotes number of objects.

The research is based on the Local Data Bank maintained by the National Statistical Office (NSO), data published by the NSO in regional statistical yearbooks, data provided by the Polish Ministry of Finance and Eurostat Regional Statistics.The right selection of diagnostic characteristics is particularly important because the results of the research 
depend to a large extent on it (Nowak, 1990: 23-28). In the analysis a total number of 30 diagnostic variables have been used to construct the synthetic index of socio-economic potential. After elimination of variables which were highly correlated (the Pearson correlation coefficient equal or higher than $0.8^{3}$ ) and were not diversified enough (the coefficient of variation lover than 0.10 ), 15 variables were left to conduct the analysis (see Tab. 1) ${ }^{4}$. All the selected variables were equally weighted.

Tab. 1. Variables used in the analysis

\begin{tabular}{|c|l|c|}
\hline No. & \multicolumn{1}{|c|}{ variable } & $\mathrm{s} / \mathrm{d}$ \\
\hline $\mathrm{X}_{1}$ & population growth per thousand population & $\mathrm{s}$ \\
\hline $\mathrm{X}_{2}$ & infant mortality rate per thousand live births & $\mathrm{d}$ \\
\hline $\mathrm{X}_{3}$ & $\begin{array}{l}\text { registered unemployment rate (as a relation of the number of registered unemployed to } \\
\text { economically active population) }\end{array}$ & $\mathrm{d}$ \\
\hline $\mathrm{X}_{4}$ & long-term unemployment rate & $\mathrm{d}$ \\
\hline $\mathrm{X}_{5}$ & GDP per capita, EUR & $\mathrm{s}$ \\
\hline $\mathrm{X}_{6}$ & dwellings completed per thousand population & $\mathrm{s}$ \\
\hline $\mathrm{X}_{7}$ & entities of the economy entered in the REGON register per thousand population & $\mathrm{s}$ \\
\hline $\mathrm{X}_{8}$ & $\begin{array}{l}\text { share of entities of the economy removed from the REGON register in the total number of } \\
\text { entities entered in the register }\end{array}$ & $\mathrm{s}$ \\
\hline $\mathrm{X}_{9}$ & share of local government investment expenditure in total expenditure & $\mathrm{s}$ \\
\hline $\mathrm{X}_{10}$ & local government debt to revenues & $\mathrm{d}$ \\
\hline $\mathrm{X}_{11}$ & public hard surface roads per 100 km ${ }^{2}$ & $\mathrm{~s}$ \\
\hline $\mathrm{X}_{12}$ & doctors entitled to practise medical profession per 10 thousand population & $\mathrm{s}$ \\
\hline $\mathrm{X}_{13}$ & outlays on fixed assets serving environmental protection per 1 inhabitant, PLN & $\mathrm{s}$ \\
\hline $\mathrm{X}_{14}$ & foundations, associations and social organizations per 10 thousand population & $\mathrm{s}$ \\
\hline $\mathrm{X}_{15}$ & population aged 25-64 with tertiary educational attainment level & $\mathrm{s}$ \\
\hline
\end{tabular}

s - stimulant, d - de-stimulant

Source: own elaboration

\section{RESUlts of EMPIRICAL ANALYSIS}

The selected regions differ in terms of the structure of economy, economic, geographical, historical and social conditions. The highest coefficient of variation of selected variables was recorded for population growth per thousand population, local government debt to revenues, dwellings completed per thousand population, public hard surface roads per $100 \mathrm{~km}^{2}$, outlays on fixed assets serving environmental protection

${ }^{3}$ In most cases it was less than 0.6. The highest correlation was reported between entities of the economy and GDP per capita $(0.74 ; 0.72$; and 0.78$)$ and between population with tertiary educational attainment and doctors entitled to practise medical profession $(0.78 ; 0.70 ; 0.74)$.

${ }^{4}$ Other variables such as gross fixed assets per inhabitant, investment outlays per inhabitant, industrial production per inhabitant, household income, employment rate, net migration, the usable floor area of flats per inhabitant, share of population with social benefits, etc. were considered in the analysis but due to high correlation and/or low coefficient of variation in at least one of the analysed years they were omitted. 


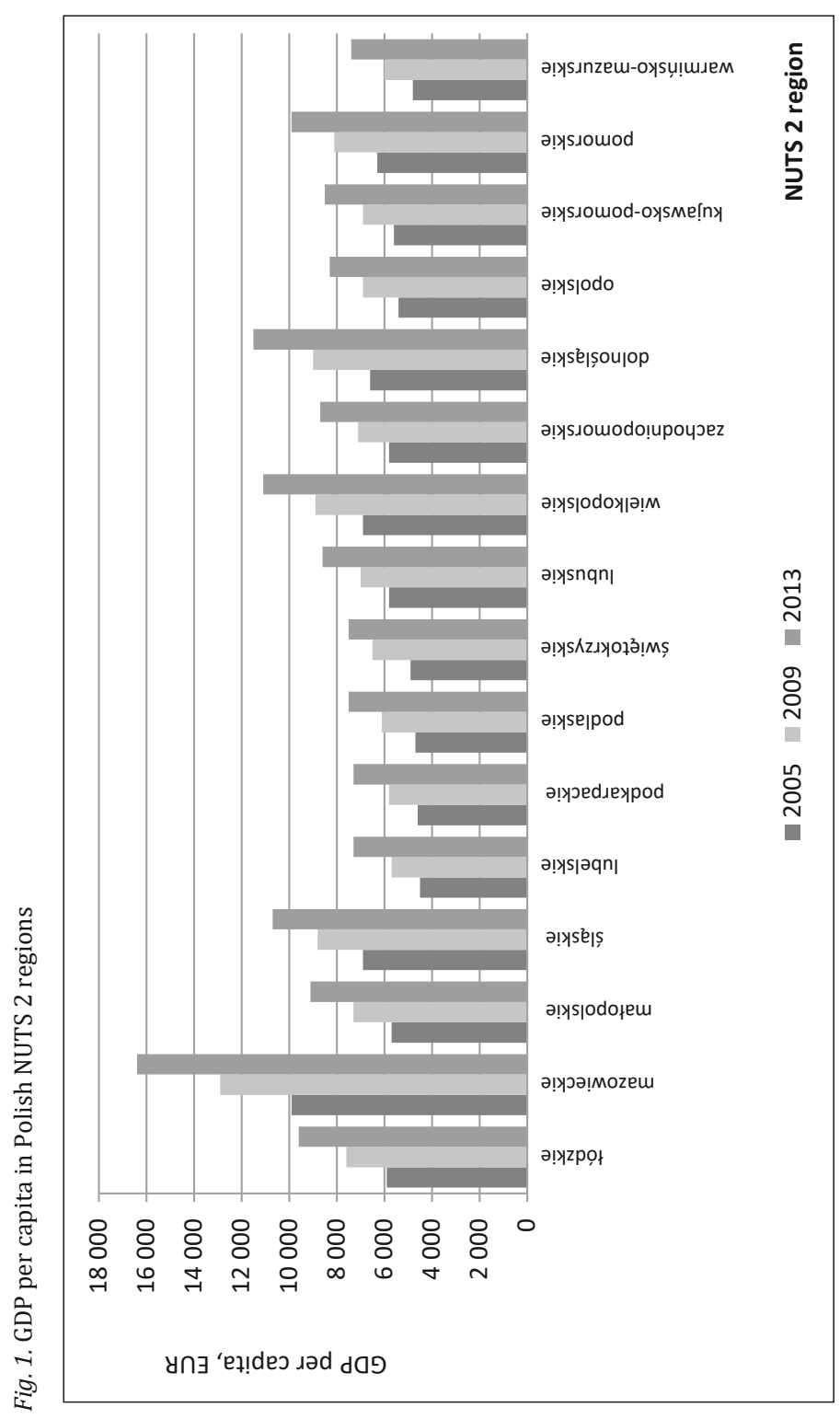

5
0
0
0
0
$\frac{\pi}{0}$
0
5
0
0
0
0
0
0 
per 1 inhabitant and share of entities of the economy removed from the REGON register. The lowest variance was observed for infant mortality, share of local government investment expenditure in total expenditure, and foundations, associations and social organizations per 10 thousand population.

Analysis of GDP per capita as a fundamental measure of economic development shows considerable regional differences (figure 1). In each selected year, GDP per capita of the poorest region was more than two times lower than GDP per capita of the best performing region. The regions with the highest value of the measure were Mazowieckie, Śląskie, Dolnośląskie, Wielkopolskie and Pomorskie. The lowest GDP per capita had been continuously located in the Eastern Poland regions, however their positions in the rankings evolved in the years considered (table 2).

Tab. 2. Ranking of NUTS-2 rgions according to GDP per capita

\begin{tabular}{|c|l|l|l|}
\hline rank & \multicolumn{2}{|c|}{2005} & \multicolumn{2}{|c|}{2013} \\
\hline 1. & Mazowieckie & Mazowieckie & Mazowieckie \\
\hline 2. & Śląskie & Dolnośląskie & Dolnośląskie \\
\hline 3. & Wielkopolskie & Wielkopolskie & Wielkopolskie \\
\hline 4. & Dolnośląskie & Śląskie & Śląskie \\
\hline 5. & Pomorskie & Pomorskie & Pomorskie \\
\hline 6. & Łódzkie & Łódzkie & Łódzkie \\
\hline 7. & Lubuskie & Małopolskie & Małopolskie \\
\hline 8. & Zachodniopomorskie & Zachodniopomorskie & Zachodniopomorskie \\
\hline 9. & Małopolskie & Lubuskie & Lubuskie \\
\hline 10. & Kujawsko-Pomorskie & Opolskie & Kujawsko-Pomorskie \\
\hline 11. & Opolskie & Kujawsko-Pomorskie & Opolskie \\
\hline 12. & Świętokrzyskie & Świętokrzyskie & Podlaskie \\
\hline 13. & Warmińsko-Mazurskie & Podlaskie & Świętokrzyskie \\
\hline 14. & Podlaskie & Warmińsko-Mazurskie & Warmińsko-Mazurskie \\
\hline 15. & Podkarpackie & Podkarpackie & Lubelskie \\
\hline 16. & Lubelskie & Lubelskie & Podkarpackie \\
\hline
\end{tabular}

Source: own elaboration

The scores of rankings carried out using selected methods of multidimensional comparative analysis are presented in table 3 . The values of synthetic measures are presented in the annex. Capital region ranks first in all the analysed years, followed by according to the method of pattern of development - Wielkopolskie and Pomorskie in 2005, Pomorskie and Małopolskie in 2009 and Małopolskie and Dolnośląskie in 2013. The worst performers were Warmińsko-Mazurskie, Lubelskie (except for 2013) and Kujawsko-Pomorskie.

High GDP per capita does not always correspond to high social potential. This is a case, for example, of Śląskie with the second highest GDP per capita and socio-economic potential ranked even ninth in 2005, seventh in 2009 and sixth in 2013. Its low position results from low values of demographic potential variables, high long-term unemployment rate, low number of dwellings completed, foundations, associations and social organizations and relatively low share of population with tertiary educational 
attainment level. Good examples are also the poorest Eastern Poland regions (except for Warmińsko-Mazurskie). In 2013, according to all the selected methods, these regions scored middle in the rankings. The differences are also visible in case of $\mathrm{Ku}$ jawsko-Pomorskie, Lubuskie and Łódzkie which scored middle by GDP per capita and low by socio-economic potential. In 2013, eight position in the ranking by GDP per capita for Zachodniopomorskie did not correspond with its rather lower position by socio-economic potential.

Tab. 3. The rankings of regions on the basis of the use of selected methods of multidimensional comparative analysis

\begin{tabular}{|l|c|c|c|c|c|c|c|c|c|}
\cline { 2 - 11 } \multicolumn{1}{c|}{} & \multicolumn{3}{c}{ Hellwig's method } & \multicolumn{3}{c}{ method of standardised } & \multicolumn{4}{c|}{ method of ranks } \\
\hline NUTS-2 & 2005 & 2009 & 2013 & 2005 & 2009 & 2013 & 2005 & 2009 & 2013 \\
\hline Łódzkie & 8 & 10 & 13 & 9 & 11 & 13 & 7 & 8 & 13 \\
\hline Mazowieckie & 1 & 1 & 1 & 1 & 1 & 1 & 1 & 1 & 1 \\
\hline Małopolskie & 4 & 3 & 2 & 4 & 3 & 2 & 4 & 3 & 4 \\
\hline Śląskie & 9 & 7 & 6 & 6 & 6 & 6 & 9 & 6 & 6 \\
\hline Lubelskie & 15 & 16 & 7 & 15 & 14 & 9 & 14 & 14 & 9 \\
\hline Podkarpackie & 14 & 12 & 8 & 14 & 12 & 8 & 15 & 13 & 7 \\
\hline Podlaskie & 13 & 8 & 9 & 12 & 8 & 7 & 11 & 9 & 8 \\
\hline Świętokrzyskie & 11 & 9 & 10 & 11 & 9 & 10 & 12 & 10 & 10 \\
\hline Lubuskie & 5 & 11 & 14 & 5 & 10 & 14 & 5 & 11 & 14 \\
\hline Wielkopolskie & 2 & 5 & 5 & 3 & 5 & 5 & 3 & 5 & 5 \\
\hline $\begin{array}{l}\text { Zachodniopo- } \\
\text { morskie }\end{array}$ & 7 & 6 & 11 & 7 & 7 & 12 & 8 & 7 & 12 \\
\hline Dolnośląskie & 6 & 4 & 3 & 8 & 4 & 4 & 6 & 4 & 3 \\
\hline Opolskie & 10 & 13 & 12 & 10 & 13 & 11 & 10 & 12 & 11 \\
\hline $\begin{array}{l}\text { Kujawsko- } \\
\text { Pomorskie }\end{array}$ & 12 & 15 & 15 & 13 & 16 & 15 & 13 & 16 & 16 \\
\hline Pomorskie & 3 & 2 & 4 & 2 & 2 & 3 & 2 & 2 & 2 \\
\hline $\begin{array}{l}\text { Warmińsko- } \\
\text { Mazurskie }\end{array}$ & 16 & 14 & 16 & 16 & 15 & 16 & 16 & 15 & 15 \\
\hline
\end{tabular}

Source: own elaboration, the sequence of regions by Local Data Bank

The comparison of ranks obtained by using the Hellwig's method in 2005 to 2009 and 2013 shows decreasing compatibility and thus growing diversification of positions of selected regions. The values of the Spearman's rank correlation coefficient decreased from 0.829 in 2009 to 0.582 in 2013. In 2009, 7 out of 16 Polish regions have improved their ranking positions in comparison to the year 2005. In 2013, their number decreased to 6. The group included Małopolskie, Śląskie, Lubelskie, Podkarpackie, Podlaskie, Świętokrzyskie and Dolnośląskie. The highest decrease in 2013 in comparison to the year 2005 experienced Lubuskie (-9) and Łódzkie (-5). The only region that in all the analysed years maintained its position was the capital region. The calculated synthetic measure became the basis for clustering of regions (divided into quartiles). The results present table 4 and the following figures. 
Tab. 4. Categorisation of regions (synthetic measure of development by Hellwig)

\begin{tabular}{|c|c|c|c|}
\hline $\begin{array}{l}\text { socio- } \\
\text {-economic } \\
\text { potential }\end{array}$ & 2005 & 2009 & 2013 \\
\hline $\begin{array}{l}\text { the highest } \\
\text { (group 1) }\end{array}$ & $\begin{array}{l}\text { Mazowieckie, } \\
\text { Wielkopolskie, } \\
\text { Pomorskie, } \\
\text { Małopolskie }\end{array}$ & $\begin{array}{l}\text { Mazowieckie, Pomorskie, } \\
\text { Małopolskie, Dolnośląskie }\end{array}$ & $\begin{array}{l}\text { Mazowieckie, } \\
\text { Małopolskie, } \\
\text { Dolnośląskie, Pomorskie }\end{array}$ \\
\hline $\begin{array}{l}\text { middle } \\
\text { (group 2) }\end{array}$ & $\begin{array}{l}\text { Lubuskie, } \\
\text { Dolnośląskie, } \\
\text { Zachodniopomorskie, } \\
\text { Łódzkie }\end{array}$ & $\begin{array}{l}\text { Wielkopolskie, } \\
\text { Zachodniopomorskie, } \\
\text { Śląskie, } \\
\text { Podlaskie }\end{array}$ & $\begin{array}{l}\text { Wielkopolskie, } \\
\text { Śląskie, } \\
\text { Lubelskie, } \\
\text { Podkarpackie }\end{array}$ \\
\hline $\begin{array}{l}\text { low } \\
\text { (group 3) }\end{array}$ & $\begin{array}{l}\text { Śląskie, } \\
\text { Opolskie, Świętokrzyskie, } \\
\text { Kujawsko-Pomorskie }\end{array}$ & $\begin{array}{l}\text { Świętokrzyskie, Łódzkie, } \\
\text { Lubuskie, } \\
\text { Podkarpackie }\end{array}$ & $\begin{array}{l}\text { Podlaskie, } \\
\text { Świętokrzyskie, } \\
\text { Zachodniopomorskie, } \\
\text { Opolskie }\end{array}$ \\
\hline $\begin{array}{l}\text { the lowest } \\
\text { (group 4) }\end{array}$ & $\begin{array}{l}\text { Podlaskie, } \\
\text { Podkarpackie, } \\
\text { Lubelskie, } \\
\text { Warmińsko-Mazurskie }\end{array}$ & $\begin{array}{l}\text { Opolskie, } \\
\text { Warmińsko-Mazurskie, } \\
\text { Kujawsko-Pomorskie, } \\
\text { Lubelskie }\end{array}$ & $\begin{array}{l}\text { Łódzkie, } \\
\text { Lubuskie, } \\
\text { Kujawsko-Pomorskie, } \\
\text { Warmińsko-Mazurskie }\end{array}$ \\
\hline
\end{tabular}

Source: own elaboration

Fig. 2. Categorisation of NUTS-2 regions in Poland 2005

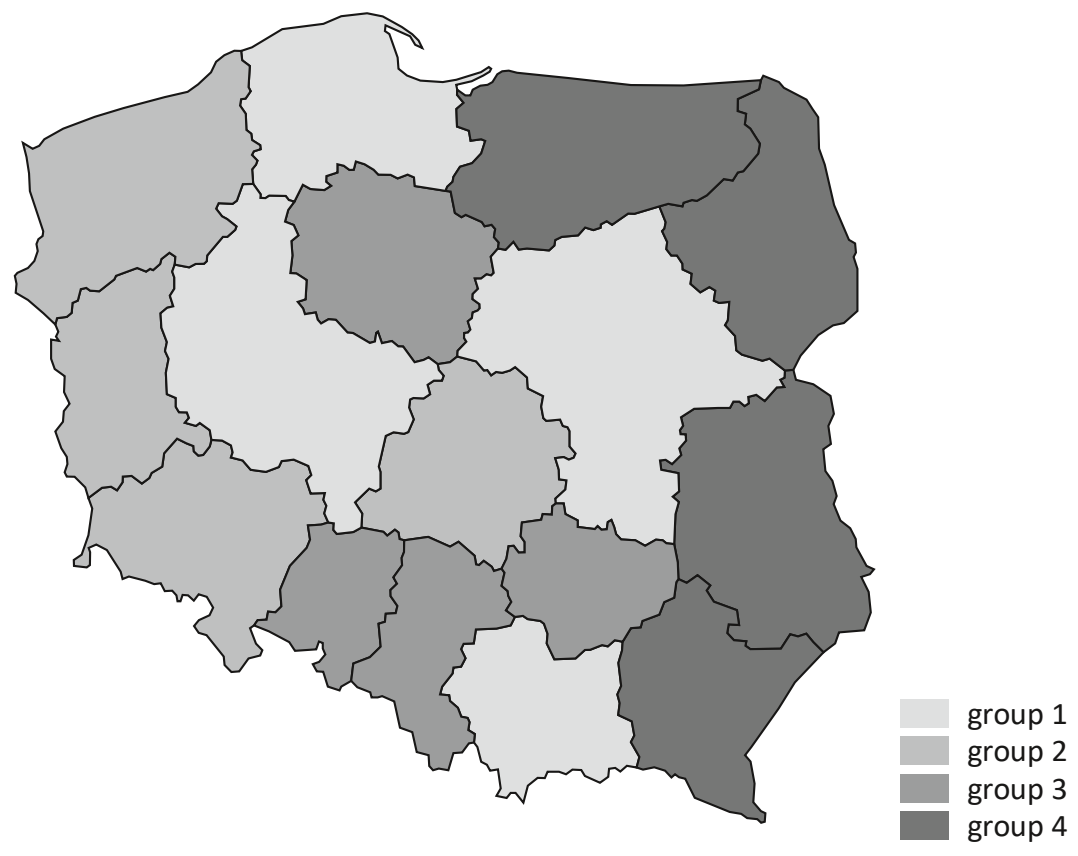

Source: own elaboration 
Fig. 3. Categorisation of NUTS-2 regions in Poland 2009

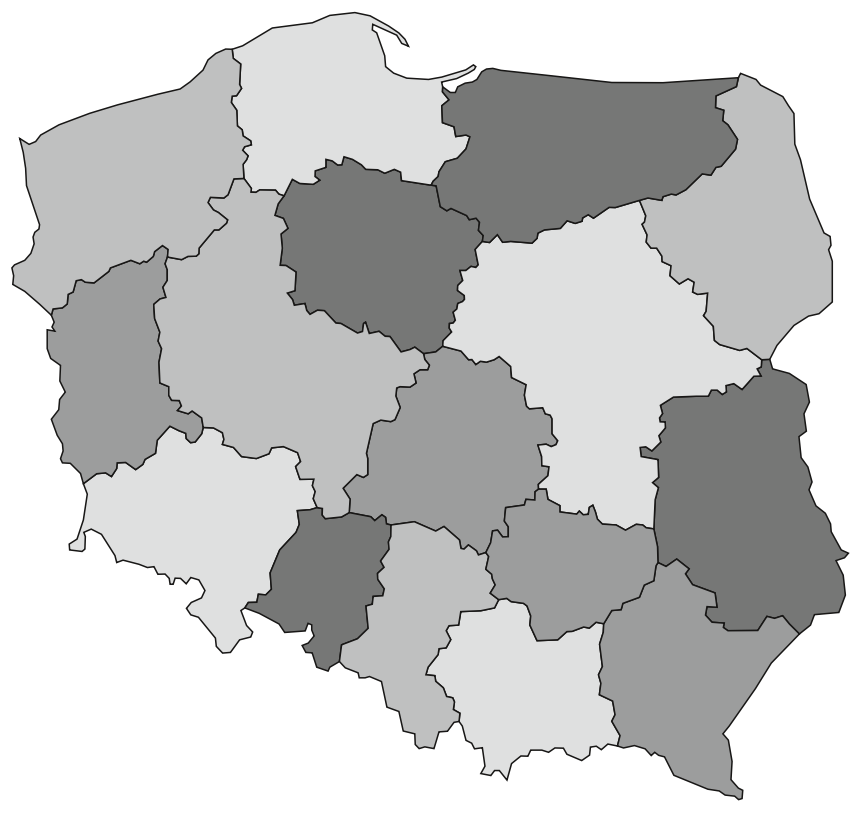

Source: own elaboration

Fig. 4. Categorisation of NUTS-2 regions in Poland 2013

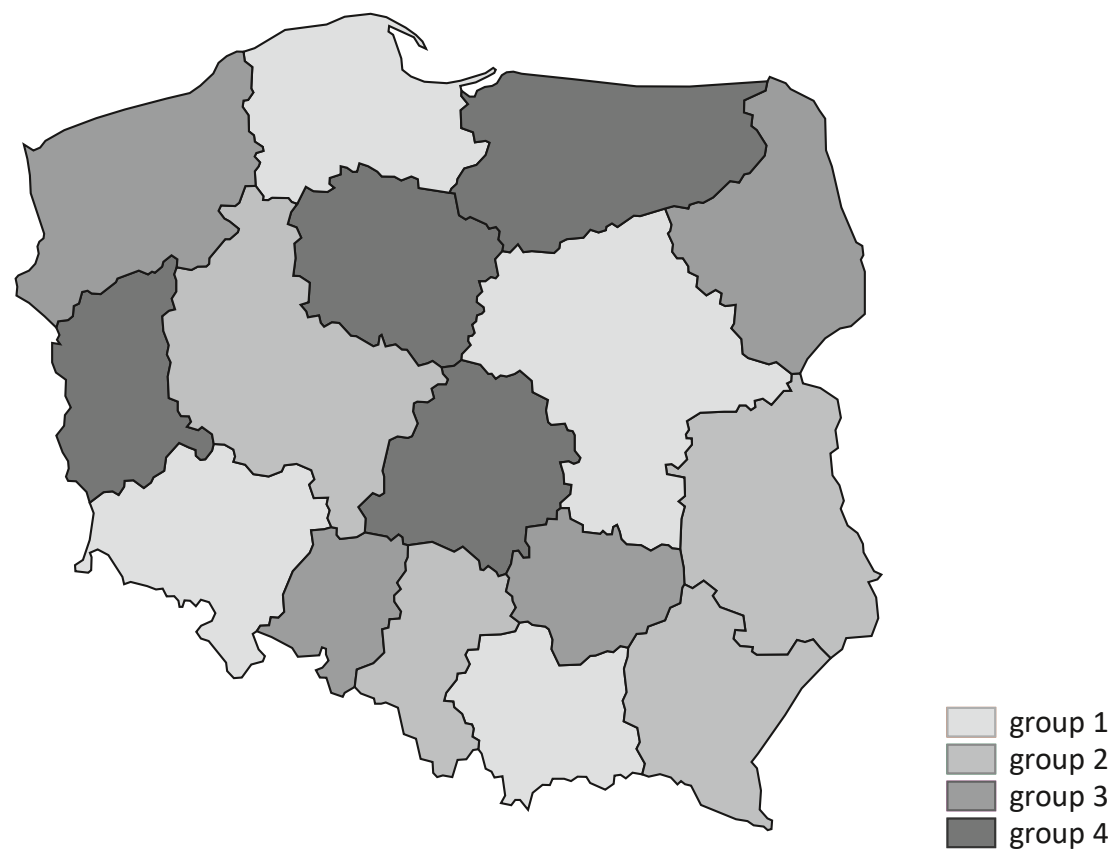

Source: own elaboration 
In 2005, the group of regions with the highest socio-economic potential formed Mazowieckie, Wielkopolskie, Małopolskie and Pomorskie. Over subsequent years, Wielkopolskie was replaced by Dolnośląskie. The group of regions with middle socio-economic potential included also the regions with the lowest level of GDP per capita, such as Podlaskie in 2009 and Lubelskie and Podkarpackie in 2013. In all the analysed years the only region that remained continuously in the group of low potential was Świętokrzyskie. In 2005, the group of regions with the lowest socio-economic potential consisted solely of the Eastern Poland regions. Afterwards, the group was joined by economically better performing regions such as Opolskie and Kujawsko-Pomorskie (in 2009) and Kujawsko-Pomorskie, Łódzkie and Lubuskie (in 2013). The latter two regions changed the group twice, from middle to low in 2009 and from low to the lowest in the last analysed year. Results of different grouping method based on mean and standard deviation are slightly different. It is interesting to note that only in 2005 the capital region stood out from the other regions. In 2009 the group of best performers formed four regions and in 2013 three regions (without Pomorskie). In turn the lowest group consisted of two regions in 2005 (Warmińsko-Mazurskie and Lubelskie), three in 2009 (without Opolskie) and three in 2013 (without Łódzkie).

High (close to one) values of the Spearman's rank correlation coefficient confirmed significant compatibility of the results obtained using the pattern of development method proposed by Hellwig, the method of standardised values and the method of ranks (table 5).

Tab. 5. The comparison of the compatibility of rankings by the Spearman's rank correlation coefficient

\begin{tabular}{|c|c|c|c|}
\hline Methods & 2005 & 2009 & 2013 \\
\hline $\begin{array}{l}\text { the method of pattern of development - the method of standardised } \\
\text { values }\end{array}$ & 0.974 & 0.985 & 0.982 \\
\hline the method of pattern of development - the method of ranks & 0.982 & 0.976 & 0.974 \\
\hline the method of standardised values - the method of ranks & 0.968 & 0.979 & 0.985 \\
\hline
\end{tabular}

Source: own elaboration

The position of each region was influenced by a series of variables. The regions have been ranked according to each of fifteen indicators. In all the analysed years the lowest population growth was recorded in Łódzkie and the highest in Pomorskie. In 2013, their values were -3.5 per cent and 1.7 per cent respectively. In 2005 , there was a negative population growth in 8 out of 16 Polish regions. In the last analysed year, the number of regions with negative population growth has increased to 11 regions. The highest infant mortality rate was recorded in Śląskie, Zachodniopomorskie and Dolnośląskie. In the analysed years, the regions with the lowest unemployment rate were, apart from the capital region, Wielkopolskie, Śląskie and Małopolskie. In 2013, these rates were 9.6 per cent, 11.3 per cent and 11.5 per cent respectively. In the same time, the highest rates were recorded for Warmińsko-Mazurskie - 21.6 per cent, Kujawsko-Pomorskie - 18.2 per cent and Zachodniopomorskie - 18 per cent. The regions with the highest long-term unemployment rate were, apart from the Eastern Poland 
regions, Łódzkie, Małopolskie and Wielkopolskie. In 2013, the regions with the lowest rates were Lubuskie (23.3 per cent), Opolskie (25 per cent) and Mazowieckie (28.7 per cent).

The highest number of dwellings completed per thousand population was recorded in Mazowieckie (5.5 in both 2005 and in 2013) and Pomorskie (4.5 in 2013 and 5.2 in 2013), and in 2013 in Dolnośląskie (5.65). The lowest number was in Łódzkie, Śląskie, Podkarpackie, Świętokrzyskie and Opolskie. In 2005, more than 100 entities of the economy entered in the REGON register per thousand population were in 6 out of 16 Polish regions. These regions were: Mazowieckie, Lubuskie, Wielkopolskie, Zachodniopomorskie, Dolnośląskie and Pomorskie. In 2013, the group has included 9 regions. It has been extended to Małopolskie, Śląskie and Opolskie. Starting from the year 2009 (the period of economic downturn), the highest share of entities of the economy removed from the REGON register in the total number of entities entered in the register was recorded in Kujawsko-Pomorskie, Warmińsko-Mazurskie, Łódzkie, Podlaskie and Lubuskie. In 2009, the highest share reached 19.2 per cent (Łódzkie), in 2013, much less - 7.9 per cent (Kujawsko-Pomorskie).

Activity and financial stability of local government varied widely from region to region and from year to year. In 2013, the share of local government investment expenditure in total expenditure was the highest in 4 Eastern Poland regions: Podkarpackie (21.5 per cent), Świętokrzyskie (21.3 per cent), Podlaskie (21 per cent) and Lubelskie (21.7 per cent), which could be linked to the implementation of investment, particularly infrastructural projects co-financed by EU funds. In 2013, the first three regions with the highest share of local government investment were at the same time the regions with the lowest local government debt (see table 9). It may result from government support they benefit from as the poorest Polish regions, including inter alia the tax paid by the richest for the poorest regions called "janosikowe". In both, 2009 and 2013, the highest local government debt was found in Mazowieckie, 43 per cent and 73 per cent respectively (in comparison to 1.5 per cent in 2005). The high level of debt could be in this case a result of the aforementioned tax paid by Mazowieckie and loans for the payment of its shares in investments co-financed by EU structural funds. In turn, low share of local government investment expenditure may be linked to high total expenditure incurred by the capital region. Despite indicators of the deteriorating financial situation of regional self-government, total expenditure increased more rapidly than revenues. It was determined by the implementation of numerous infrastructural projects in Polish regions. But one has to remember that finally the debts have to be serviced.

In Poland, there are spatial imbalances in the sphere of the development of road infrastructure. Apart from the Eastern Poland regions (except for Świętokrzyskie), low public hard surface roads density in the year 2013 was found in Zachodniopomorskie (59.8 km per $100 \mathrm{~km}^{2}$ ), Lubuskie (60.6 km per $100 \mathrm{~km}^{2}$ ) and Pomorskie $(70.2 \mathrm{~km}$ per $100 \mathrm{~km}^{2}$ ). In all the analysed years, the highest density was in Śląskie, Małopolskie and Świętokrzyskie. Access to health care measured as doctors entitled to practise medical profession per 10 thousand population was also diversified. The easiest access 
was found in Mazowieckie, Łódzkie and Podlaskie, the most difficult in Lubuskie, Podkarpackie, Opolskie and Warmińsko-Mazurskie. Most expenditure on environmental protection per 1 inhabitant has been incurred in Opolskie, Śląskie and Łódzkie. Social capital measured as a number of foundations, associations and social organizations per 10 thousand population was one of the variables with the lowest coefficient of variation. Its lowest level was recorded in Śląskie, Kujawsko-Pomorskie, Świętokrzyskie and Łódzkie. In 2013, the number of foundations, associations and social organizations varied from 23 in Śląskie to 34 in Dolnośląskie and Warmińsko-Mazurskie. The last analysed variable was the share of population with tertiary educational attainment level, treated as a measure of human capital and innovative potential. In 2005, its share varied from 23.5 per cent in Mazowieckie to 13.3 per cent in Kujawsko-Pomorskie and in 2009 from 29.3 per cent in Mazowieckie to 16.2 per cent in Opolskie. In the last analysed year, the values amounted respectively 35.4 per cent (Mazowieckie) and 20.6 per cent (Lubuskie).

The findings confirmed significant compatibility of results obtained using selected methods of multidimensional comparative analysis. It means that in the analysis of socio-economic potential of Polish regions one of them could be used. Comparison of rankings of synthetic indicators and GDP per capita revealed significant differences.

\section{CONCLUSIONS}

Polish NUTS-2 regions are characterised by high diversity of socio-economic potential. The differences in economic development are still significant, in particular between the Eastern Poland- and the Western Poland regions. The level of social potential does not always correspond to the level of economic development. The group of regions with the lowest socio-economic potential formed, except for 2005, also regions with middle level of GDP per capita. In case of Śląskie, high GDP per capita does not ensure a leading position in socio-economic potential. Positions of the poorest Polish regions were diverse and varying over time. The region with the most stable and, in addition, the lowest socio-economic potential remained Warmińsko-Mazurskie. Positions in rankings of analysed regions showed growing diversity in subsequent years which was confirmed by the decreasing values of the Spearman's rank correlation coefficient. The synthetic measure used in the analysis is composed of 15 variables, of greater or lesser variance. The highest coefficient of variation was recorded inter alia for population growth per thousand population, dwellings completed per thousand population, public hard surface roads per 100 $\mathrm{km} 2$, and local government debt to revenues. High values of the latter measure may not always originate from mismanagement but also from implementation of expensive and much needed infrastructural project. Its low value may be also connected with government support. However, as debt, it has to be serviced and as such is treated as de-stimulant. 


\section{ANNEX}

Tab. 6. Values of synthetic measures

\begin{tabular}{|c|c|c|c|c|c|c|c|c|c|}
\hline \multirow{2}{*}{$\begin{array}{c}\text { NUTS } 2 \\
\text { region }\end{array}$} & \multicolumn{3}{|c|}{$\begin{array}{c}\text { The method of pattern of } \\
\text { development (Hellwig), di }\end{array}$} & \multicolumn{3}{|c|}{$\begin{array}{c}\text { The method of } \\
\text { standardised values }\end{array}$} & \multicolumn{3}{|c|}{ The method of ranks } \\
\cline { 2 - 11 } & 2005 & 2009 & 2013 & 2005 & 2009 & 2013 & 2005 & 2009 & 2013 \\
\hline PL 11 & 0.250 & 0.176 & 0.155 & -0.024 & -0.188 & -0.268 & 8.33 & 8.60 & 9.67 \\
\hline PL 12 & 0.618 & 0.448 & 0.457 & 1.309 & 0.948 & 1.140 & 3.60 & 4.53 & 4.00 \\
\hline PL 21 & 0.343 & 0.371 & 0.352 & 0.280 & 0.413 & 0.405 & 7.00 & 6.33 & 6.67 \\
\hline PL 22 & 0.225 & 0.214 & 0.250 & 0.062 & 0.157 & 0.151 & 8.47 & 7.87 & 7.67 \\
\hline PL 31 & 0.119 & 0.088 & 0.209 & -0.545 & -0.443 & -0.097 & 10.73 & 10.47 & 9.40 \\
\hline PL 32 & 0.128 & 0.155 & 0.200 & -0.450 & -0.240 & -0.061 & 10.87 & 10.13 & 8.80 \\
\hline PL 34 & 0.173 & 0.179 & 0.193 & -0.269 & -0.090 & -0.037 & 9.27 & 8.73 & 8.93 \\
\hline PL 33 & 0.206 & 0.177 & 0.185 & -0.246 & -0.161 & -0.124 & 9.73 & 9.53 & 9.40 \\
\hline PL 43 & 0.304 & 0.176 & 0.105 & 0.215 & -0.173 & -0.383 & 8.00 & 9.53 & 10.40 \\
\hline PL 41 & 0.386 & 0.294 & 0.308 & 0.347 & 0.220 & 0.249 & 6.27 & 7.20 & 7.00 \\
\hline PL 42 & 0.262 & 0.240 & 0.180 & -0.008 & 0.003 & -0.228 & 8.40 & 8.33 & 9.60 \\
\hline PL 51 & 0.290 & 0.350 & 0.337 & -0.012 & 0.247 & 0.294 & 8.13 & 7.07 & 6.47 \\
\hline PL 52 & 0.217 & 0.149 & 0.160 & -0.039 & -0.258 & -0.191 & 9.07 & 9.93 & 9.53 \\
\hline PL 61 & 0.174 & 0.089 & 0.087 & -0.274 & -0.580 & -0.496 & 10.07 & 11.53 & 11.13 \\
\hline PL 63 & 0.384 & 0.415 & 0.326 & 0.369 & 0.611 & 0.325 & 6.07 & 5.00 & 6.27 \\
\hline PL 62 & 0.059 & 0.090 & 0.012 & -0.714 & -0.467 & -0.679 & 12.00 & 11.20 & 11.07 \\
\hline
\end{tabular}

Source: own elaboration

\section{References}

Bański, J., Czapiewski, K.Ł. (2008). Ekspertyza. Identyfikacja i ocena czynników sukcesu społeczno-gospodarczego na obszarach wiejskich. Warszawa: Instytut Geografii i Przestrzennego Zagospodarowania PAN.

Bobrowska, A., Piasecka, A. (2005). Sytuacja społeczno-gospodarcza regionu a bezrobocie na przykładzie woj. opolskiego. In: D. Kopycińska (ed.). Konkurencyjność rynku pracy i jego podmiotów. Szczecin: Katedra Mikroekonomii Uniwersytetu Szczecińskiego, 145-152.

Cheymetova, V.A., Nazmutdinova, V.N. (2015). Socio-Economic Potential of the Region and Its Evaluation. Asian Social Science, 11(7), 74-81.

Chojnicki, Z. (2010). Socio-economic development and its axiological aspects. Quaestiones Geographicae, 29(2), 7-17, DOI: 10.2478/v10117-010-0010-9

Domański, B. (2004). Zróżnicowanie i warunki gospodarki regionów. Suplement do dyskusji na temat teorii Alfreda Löscha. Przegląd Geograficzny, 74(2), 157-178.

Hellwig, Z. (1968). Zastosowanie metody taksonomicznej do typologicznego podziału krajów ze względu na poziom ich rozwoju i strukturę wykwalifikowanych kadr. Przegląd Statystyczny, 4, 307-326.

Hellwig, Z., Ostasiewicz, S., Siedlecka, U., Siedlecki, J. (1994). Studia nad rozwojem gospodarczym Polski. Warszawa: Instytut Rozwoju i Studiów Strategicznych.

Jaffee, D. (1998). Levels of Socio-economic Theory. London: Praeger Publishers.

Kopyściański, T., Rólczyński, T. (2013). Analiza porównawcza potencjału gospodarczego regionów w Polsce w latach 2006-2012. Zarządzanie i Finanse, 11(3), 115-127.

Łatuszyńska, A. (2012). Overview of Approaches to Incorporate Dynamics into the Measurement of Complex Phenomena with the Use of Composite Indices. Contemporary Economics, 6(2), 64-73.

Łuczak, A., Wysocki, F. (2013). Zastosowanie mediany przestrzennej Webera i metody TOPSIS w ujęciu pozycyjnym do konstrukcji syntetycznego miernika rozwoju. In: K. Jajuga, M. Walesiak (ed.). Taksonomia 
20, Klasyfikacja i analiza danych - teoria i zastosowania. Prace Naukowe Uniwersytetu Ekonomicznego we Wrocławiu, 278, 61-73.

Malina, A. (2004). Wielowymiarowa analiza przestrzennego zróżnicowania struktury gospodarki Polski według województw. Kraków: Wydawnictwo Akademii Ekonomicznej w Krakowie.

Marciniak, S. (ed.). (2005). Makro- i mikroekonomia. Podstawowe problemy. Warszawa: Wydawnictwo Naukowe PWN.

Męczyński, M., Konecka-Szydłowska, B., Gadziński, J. (2010). (2016, 26 June) Poziom rozwoju społeczno-gospodarczego i klasyfikacja małych miast $w$ Wielkopolsce. Ekspertyza, https://www.umww.pl/attachments/article/11578/4.Poziom\%20rozwoju\%20spo\%C5\%82ecznogospodarczego\%20i\%20klasyfikacja $\% 20$ ma\%C5\%82ych\%20miast $\% 20$ w\%20Wiel .pdf

Nowak, E. (1990). Metody taksonomiczne w klasyfikacji obiektów społeczno-gospodarczych. Warszawa: PWE. Stec, M. (2008). Ranking poziomu rozwoju krajów Unii Europejskiej. Gospodarka Narodowa, 7-8, 99-118.

Stec, M. (2013). Analiza rozwoju społeczno-gospodarczego powiatów województwa podkarpackiego w latach 2002-2010. In: B. Pawełek (ed.), Zastosowanie metod ilościowych i jakościowych w modelowaniu i prognozowaniu zjawisk społeczno-gospodarczych. Kraków: Wydawnictwo Uniwersytetu Ekonomicznego w Krakowie, 254-274.

Strahl, D. (ed.). (2006). Metody oceny rozwoju regionalnego. Wrocław: Wydawnictwo AE we Wrocławiu.

Szirmai, A. (2005). Dynamics of socio-economic development: an introduction. Cambridge: Cambridge University Press.

Szirmai, A. (2015). Socio-economic Development. Cambridge University Press.

The United Nations Statistics Division. Retived from http://unstats.un.org/unsd/environment/indicators. htm

Ziemiańczyk, U. (2010). Ocena poziomu rozwoju społeczno-gospodarczego gmin wiejskich i miejsko-wiejskich w województwie małopolskim. Infrastruktura i Ekologia Terenów Wiejskich, 14, 31-40.

Anna Golejewska, Ph.D., University of Gdańsk, Faculty of Economics, Economics of European Integration Department. Author of numerous publications and lectures on regional competitiveness and innovativeness and the EU Structural Funds. Expert evaluating applications under the EU Structural Funds (ESF and ERDF) in the programming periods of 2007-2013 and 2014-2020, Member of the Regional Studies Association and the European Economics and Finance Society.

\section{Address:}

Uniwersytet Gdański

Wydział Ekonomiczny

Katedra Ekonomiki Integracji Europejskiej

ul. Armii Krajowej 119/121, 81-824 Sopot, Polska

e-mail: a.golejewska@ug.edu.pl 